\title{
МЕДИЧНА ЕКОЛОГІЯ В СИСТЕМІ ЗМЕНШЕННЯ ЗАГАЛЬНОЇ ЗАХВОРЮВАНОСТІ: ВИВЧЕННЯ ОСОБЛИВОСТЕЙ ФОТОСИНТЕТИЧНОЇ АКТИВНОСТІ МОХІВ НА ПОСТТЕХНОГЕННИХ ТЕРИТОРІЯХ ВИДОБУТКУ СІРКИ
}

\section{MEDICAL ECOLOGY IN THE SYSTEM OF REDUCING GENERAL DISEASE: STUDY OF FEATURES OF PHOTOSYNTHETIC ACTIVITY OF MOSSES ON POSTTECHNOGENIC TECHNICS}

Оксана Баїк (Oksana Baik), Інститут екології Карпат НАН України, Львів, Україна, ТзОВ «Львівський медичний інститут», Львів, Україна

Наталія Кияк (Natalya Kyyak), Інститут екології Карпат НАН України, Львів, Україна

Ольга Гуменюк (Olha Humeniuk), Львівський національний медичний університет імені Данила Галицького, Львів, Україна, ТзОВ «Львівський медичний інститут», Львів, Україна

Abstract. It is shown that bryophytes are characterized by a high content of photosynthetic pigments and the intensity of photosynthesis. The activity of photosynthetic processes of mosses depends on species characteristics and habitat. For all studied species of mosses, a direct correlation was established between the intensity of photosynthesis and the content of chlorophylls in the leaves of mosses. Analysis of the daily dynamics of moss photosynthesis demonstrated the adaptability of the moss photosynthetic apparatus to contrasting climatic conditions in the dump area and the ability to maintain the intensity of photosynthesis processes at a fairly stable level during the growing season. For the first time, the productivity of moss cover in the dump area оце 1 was estimated, which indicates the important role of bryophytes in the production process in man-made areas of sulfur production. The system of public administration in the field of water protection requires immediate reform and the transition to integrated water resources management on a basin basis. Establishment of maximum permissible concentrations of chemicals in the form of nanoparticles, the problem of low-intensity toxicity, the study of mechanisms and manifestations of cardiovasotoxic effects of exogenous chemical stimuli of industrial and environmental conditions is extremely important. The establishment of a regional program of integrated multidisciplinary research will help to study the causes and conditions of contributing to water pollution, leading to various diseases of the population, reducing the body's overall resistance and, consequently, increasing overall morbidity, including infectious and cancer diseases.

Keywords: medical ecology, general morbidity, mosses, photosynthetic pigments, intensity of moss photosynthesis, chlorophyll index. 
Вступ. Відповідно до Закону України «Про Основні засади (стратегію) державної екологічної політики України на період до 2030 року» основними джерелами забруднення вод є скиди з промислових об'єктів, неналежний стан інфраструктури водовідведення та очисних споруд, недотримання норм водоохоронних зон, змив та дренування токсичних речовин із земель сільськогосподарського призначення [38]. Основні речовини, що призводять до забруднення - сполуки важких металів, сполуки азоту та фосфору, нафтопродукти, феноли, сульфати, поверхнево-активні речовини. Останнім часом зростає забруднення медичними відходами та мікропластиком, яке на сьогодні не контролюється. Саме забруднення вод призводить до виникнення різноманітних захворювань населення, зниження загальної резистентності організму i, як наслідок, до підвищення рівня загальної захворюваності, зокрема на інфекційні та онкологічні захворювання. Діюча нині система моніторингу вод $є$ неефективною та застарілою, не відповідає сучасним європейським стандартам. Система державного управління у сфері охорони вод потребує невідкладного реформування і переходу до інтегрованого управління водними ресурсами за басейновим принципом.

Тому встановлення гранично допустимих концентрацій хімічних речовин у вигляді наночастин, вивчення проблеми токсичної дії малої інтенсивності та механізмів і проявів кардіовазотоксичної дії екзогенних хімічних подразників промислового, та навколишнього середовища $є$ вкрай актуальним. Слід зазначити, що є важливими дослідження Трахтенберга I.M., Дмитруха H.M., Короленко Т.К., Лагутіна О.С., Бакало Л.В., Легкоступ Л.А. щодо визначення токсичності розчинів $\mathrm{Fe} 2 \mathrm{O} 3$ з частинками різного розміру та оцінка ефективності застосування препарату «Кверцетин» як засобу профілактики їх негативного впливу на організм щурів [39].

Сучасні дослідження процесів формування та зміни організації фотосинтетичного апарату рослин у природних умовах $є$ необхідним як для виявлення особливостей, пов'язаних з біорізноманіттям (таксономічний аспект, тобто токсичної дії малої інтенсивності), так й у зв’язку з впливом 
різноманітних факторів середовища (медико-екологічний аспект в системі зменшення загальної захворюваності населення). Тому порівняння результатів щодо кількісних та якісних змін пігментів пластид та інтенсивності процесу асиміляції вуглекислоти в рослинах у природних умовах при складному поєднанні основних екологічних факторів середовища дає уявлення про пластичність чи консервативність обмінних процесів, виявляє ступінь пристосованості окремих видів до умов існування. Разом 3 тим, функціонування фотосинтетичного апарату рослин визначає, у кінцевому результаті, продуктивність рослинного покриву у мінливих умовах природного середовища.

Інформація про функціонування фотосинтетичного апарату та продуктивність мохів дасть можливість оцінити їх роль у збереженні біорізноманіття та внесок у загальну продуктивність рослинного покриву. На сьогодні є значна кількість монографічних робіт, присвячених, в основному, біології, систематиці, анатомії, морфології та досить коротко - фізіології мохів $[16,19,20,22,24-27 ; 34,35,37]$. Продуктивність і особливості біології мохів досліджували досить докладно на прикладі сфагнових мохів, бріофітів лісових угруповань та боліт, тундрових екосистем, крейдяних луків Європи $[6,14,17$, $18,23,36]$. Вивчення ролі бріофітів у заселенні та відновленні техногенно порушених територій практично не досліджене. У цьому аспекті унікальним об'єктом для досліджень є девастовані території Яворівського державного гірничо-хімічного підприємства (ДГХП) «Сірка», де одночасно з механічним і хімічним порушенням природних екосистем у процесі видобування сірки відкритим способом, виносяться на поверхню і складуються у відвалах гірські породи, які значно відрізняються від початкових субстратів за своїми хімічними та фізичними властивостями $[3,5,7,8]$.

Як зазначають Погребенник В.Д. та Джумеля Е.А. [40-41], екологічний моніторинг водних об'єктів Роздільського ДГХП «Сірка» $є$ актуальним i важливим, бо на гідроспорудах підприємства накопичено критичний об'єм рідини, що спричиняло періодичний аварійний скид забруднених виробничих i 
рудних вод у р. Дністер. Продовжується інтенсифікація зсуву по північному борту кар'єру в с. Малехів, що загрожує східній та північній дамбам хвостосховища №2. 155 Моніторинг підземних вод гірничо-хімічного підприємства $є$ важливою складовою в системі екологічного моніторингу, що, в свою чергу, є надзвичайно важливим для підвищення екологічної безпеки довкілля. Тому, потрібно терміново розпочати впровадження заходів, які б дали змогу оцінити сучасний стан мережі спостережних свердловин, відновити спостереження на вцілілих свердловинах, удосконалити нормативно-методичне забезпечення, реалізувати низку організаційних заходів для координації дій суб'єктів моніторингу й забезпечення ефективнішого використання інформації, що стосується стану підземних вод $[40,41]$.

Дослідженнями встановлено, що мохоподібні одними 3 перших оселяються на субстратах відвалів, формуючи $з$ часом рясні, багатовидові обростання. Важлива роль мохів, як піонерних рослин в рослинних угрупованнях, загальновідома $[21,31,32,37]$. Поступово відмираючи, піонерні види бріофітів готують субстрат для заселення інших мохів та судинних рослин. На девастованих територіях після видобутку сірки мохи формують потужний покрив з високими показниками біомаси та проективного покриття [13].

Відомо, що накопичення вуглецю у субстраті визначається здатністю фітоценозів поглинати $\mathrm{CO}_{2}$ у процесі фотосинтезу i, відповідно, опосередковано залежить від умісту хлорофілів у рослинах. Тому вивчення особливостей вмісту пігментів пластид, інтенсивності фотосинтезу мохів на території відвалу №1 ДГХП «Сірка» дасть змогу встановити їх роль у продукційному процесі рослинного покриву на техногенних субстратах сірчаного виробництва.

Матеріал і методи досліджень. На території відвалу № 1 Язівського сірчаного родовища, підпорядкованого ДГХП «Сірка», для досліджень були відібрані 4 види мохів, які є домінантами та субдомінантами в цих умовах: 
Barbula unguiculata Hedw., Bryum argenteum L., Bryum caespiticium Hedw., Brachytecium salebrosum (Web. Et Mohr) Bryol. eur. (рис. 1, a-d).
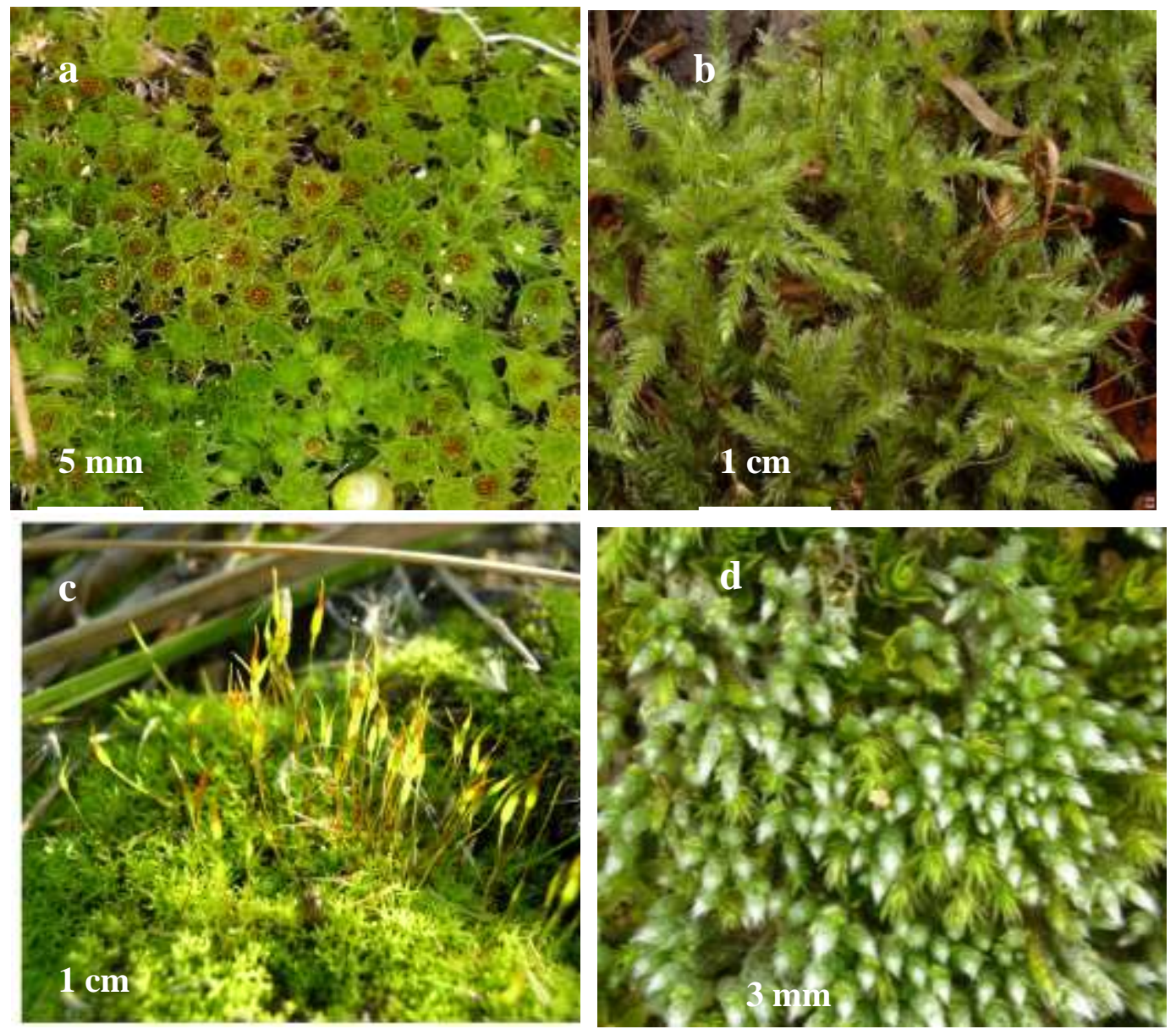

Рис. 1. Види мохів, використані для досліджень: a - Bryum caespiticium, b Brachytecium salebrosum, c - Barbula unguiculata, $\mathrm{d}$-Bryum argenteum.

Для аналізу зразки мохів збирали на 7 дослідних трансектах (гребінь відвалу та по три трансекти на північному та південному схилах - основа, схил, вершина). У свіжозібраному рослинному матеріалі визначали вміст фотосинтетичних пігментів та інтенсивність фотосинтезу. Вміст вологи у мохових дернинах визначали ваговим методом та обчислювали у відсотках від ваги абсолютно сухої речовини [9].

Вміст хлорофілів $a, b$ та каротиноїдів визначали у $80 \%$ ацетоні за методом Арнона [15]. Для цього наважку рослинного матеріалу (50-100 мг) гомогенізували у $80 \%$ ацетоні. Отриманий екстракт центрифугували за 4 тис. об/хв протягом 15 хв $\mathrm{i}$ використовували для спектрофотометричного 
визначення (Specord 210 Plus) оптичної густини при різних довжинах хвиль: 663 нм (для хлорофілу a), 645 нм (для хлорофілу $b$ ) та 470 нм (для суми каротиноїдів). Вміст пігментів виражали в мг/г маси сухої речовини.

Інтенсивність фотосинтезу визначали безкамерним способом за методикою B.I. Ніколайчука [10]. Для цього наважку свіжозібраного рослинного матеріалу (50 мг) занурювали у пробірки 3 0,4 н хромовою сумішшю і кип'ятили на водяній бані протягом 20 хв, поки проби не розчинилися (згоріли). Через 2 години дослід повторювали. Після охолодження пробірок вміст спектрофотометрично аналізували за $\lambda=590$ нм. Інтенсивність фотосинтезу виражали в мг $\mathrm{CO}_{2} /$ мг маси сухої речовини/год.

Для встановлення взаємозв'язку між інтенсивністю фотосинтезу та вмістом вологи у мохових дернинах використовували природні зразки мохів із дослідних трансект на території відвалу, в яких одночасно визначали і вміст вологи, і фотосинтетичну інтенсивність.

Запас наземної фітомаси визначали методом облікових ділянок розміром $0,25 \times 0,25$ м [1]. Наземну фітомасу сортували за видами рослин, відділяючи живі частини від відмерлих, зважували і виражали у г/м².

Для визначення хлорофільного індексу (XI) було використано величини вмісту хлорофілів $a$ і $b$ і дані по фітомасі усіх компонентів угруповання $[11,14]$. XI визначали за формулою: $X I=(x л ~ a+x л ~ в) \times$ pimомаса і виражали у $г / \mathrm{M}^{2}$.

\section{Результати досліджень та їх обговорення}

Як і кожна фізіологічна функція, фотосинтез завжди має певні риси пристосування до складного комплексу екологічних факторів та умов, в яких цей процес відбувається, і від яких залежить його перебіг. Це проявляється, в першу чергу, в особливостях пігментного апарату, в його кількісному та якісному складі.

У наших дослідах вміст хлорофілів $(a+b)$ у листках досліджуваних видів мохів був у межах $0,83-1,41$ мг/г маси сирої речовини, а каротиноїдів - 0,140,64 мг/Г маси сирої речовини. Однак, після перерахунку на суху вагу, 
відмінності між проаналізованими видами були ще більші, у зв’язку з різним вмістом сухої речовини у листках, який коливався у межах від 30\% до 60\%. Відповідно, вміст хлорофілів $(a+b)$ знаходився у діапазоні 0,4-1,9 мг/г маси сухої речовини, каротиноїдів - 0,2-0,8 мг/г маси сухої речовини. Для видів Bryum caespiticium та Bryum argenteum визначено найбільшу кількість хлорофілів (1,2-1,9 мг/г маси сухої речовини) та каротиноїдів (0,4-0,8 мг/г маси сухої речовини) (табл. 1). Можливо, це пов'язане із специфікою життєвої форми B. caespiticium та B. argenteum, оскільки вони утворюють коротку щільну або пухку дернину, яка добре утримує вологу. Максимальні покази вмісту хлорофілів у B. caespiticium можуть бути обумовлені й досить високою оводненістю листків (60-70\%), порівняно з іншими досліджуваними видами. Встановлено, що вміст фотосинтетичних пігментів у пагонах мохів залежить від експозиції та місцезнаходження.

Таблиця 1. Вміст фотосинтетичних пігментів (мг/г маси сухої речовини) у пагонах мохів на території відвалу №1.

\begin{tabular}{|c|c|c|c|c|c|c|}
\hline $\begin{array}{c}\text { Місце відбору } \\
\text { зразків } \\
\text { мохів } \\
\end{array}$ & хл. $\boldsymbol{a}$ & хл. $b$ & $a+b$ & каротиноїди & $\mathbf{X} / \mathbf{K}$ & $a / b$ \\
\hline \multicolumn{7}{|c|}{ Північний схил } \\
\hline \multicolumn{7}{|l|}{ Bryum caespiticium } \\
\hline гребінь відвалу & $0,98 \pm 0,08$ & $0,52 \pm 0,05$ & $1,50 \pm 0,09$ & $0,46 \pm 0,03$ & 3,2 & 1,9 \\
\hline основа & $0,96 \pm 0,06$ & $0,62 \pm 0,03$ & $1,58 \pm 0,10$ & $0,41 \pm 0,02$ & 3,8 & 1,6 \\
\hline схил & $0,90 \pm 0,09$ & $0,56 \pm 0,09$ & $1,46 \pm 0,09$ & $0,76 \pm 0,03$ & 1,9 & 1,6 \\
\hline вершина & $0,68 \pm 0,08$ & $0,52 \pm 0,06$ & $1,20 \pm 0,08$ & $0,31 \pm 0,01$ & 3,9 & 1,3 \\
\hline \multicolumn{7}{|l|}{ Bryum argenteum } \\
\hline гребінь відвалу & $0,70 \pm 0,06$ & $0,52 \pm 0,04$ & $1,22 \pm 0,09$ & $0,58 \pm 0,05$ & 2,1 & 1,3 \\
\hline основа & $0,68 \pm 0,03$ & $0,53 \pm 0,02$ & $1,21 \pm 0,09$ & $0,52 \pm 0,02$ & 2,3 & 1,3 \\
\hline схил & $0,62 \pm 0,01$ & $0,53 \pm 0,02$ & $1,15 \pm 0,08$ & $0,42 \pm 0,03$ & 2,7 & 1,2 \\
\hline вершина & $0,24 \pm 0,01$ & $0,16 \pm 0,01$ & $0,40 \pm 0,02$ & $0,21 \pm 0,01$ & 1,91 & 1,5 \\
\hline \multicolumn{7}{|l|}{ Barbula unguiculata } \\
\hline гребінь відвалу & $0,65 \pm 0,06$ & $0,43 \pm 0,03$ & $1,08 \pm 0,09$ & $1,18 \pm 0,05$ & 0,9 & 1,5 \\
\hline основа & $0,64 \pm 0,03$ & $0,41 \pm 0,02$ & $1,05 \pm 0,09$ & $1,21 \pm 0,01$ & 0,8 & 1,5 \\
\hline схил & $0,59 \pm 0,02$ & $0,40 \pm 0,01$ & $0,99 \pm 0,03$ & $1,12 \pm 0,03$ & 0,9 & 1,5 \\
\hline вершина & $0,39 \pm 0,01$ & $0,24 \pm 0,02$ & $0,63 \pm 0,02$ & $0,73 \pm 0,01$ & 0,8 & 1,6 \\
\hline \multicolumn{7}{|l|}{$\frac{\text { Brachytecium }}{\text { salebrosum }}$} \\
\hline основа & - & - & - & - & - & - \\
\hline схил & $0,51 \pm 0,05$ & $0,64 \pm 0,02$ & $1,15 \pm 0,02$ & $0,28 \pm 0,03$ & 4,1 & 0,8 \\
\hline
\end{tabular}




\begin{tabular}{|c|c|c|c|c|c|c|}
\hline вершина & $0,33 \pm 0,03$ & $0,30 \pm 0,01$ & $0,63 \pm 0,09$ & $0,22 \pm 0,02$ & 2,9 & 1,1 \\
\hline \multicolumn{7}{|c|}{ Південний схил } \\
\hline \multicolumn{7}{|c|}{ Bryum caespiticium } \\
\hline основа & $0,69 \pm 0,03$ & $0,54 \pm 0,03$ & $1,23 \pm 0,09$ & $0,43 \pm 0,03$ & 2,9 & 1,3 \\
\hline схил & $1,08 \pm 0,09$ & $0,68 \pm 0,04$ & $1,76 \pm 0,07$ & $0,51 \pm 0,03$ & 3,4 & 1,6 \\
\hline вершина & $0,69 \pm 0,05$ & $0,45 \pm 0,02$ & $1,14 \pm 0,09$ & $0,44 \pm 0,02$ & 2,6 & 1,6 \\
\hline \multicolumn{7}{|c|}{ Bryum argenteum } \\
\hline основа & $0,91 \pm 0,09$ & $0,58 \pm 0,03$ & $1,49 \pm 0,11$ & $0,63 \pm 0,05$ & 2,3 & 1,9 \\
\hline схил & $0,78 \pm 0,05$ & $0,45 \pm 0,02$ & $1,23 \pm 0,09$ & $0,38 \pm 0,01$ & 3,2 & 1,8 \\
\hline вершина & $0,61 \pm 0,03$ & $0,34 \pm 0,02$ & $0,95 \pm 0,07$ & $0,36 \pm 0,02$ & 2,6 & 1,8 \\
\hline \multicolumn{7}{|c|}{ Barbula unguiculata } \\
\hline основа & $0,63 \pm 0,02$ & $0,36 \pm 0,01$ & $0,99 \pm 0,04$ & $0,75 \pm 0,03$ & 1,3 & 1,6 \\
\hline схил & $0,58 \pm 0,03$ & $0,42 \pm 0,03$ & $1,03 \pm 0,08$ & $0,59 \pm 0,05$ & 1,6 & 1,3 \\
\hline вершина & $0,47 \pm 0,01$ & $0,27 \pm 0,01$ & $0,74 \pm 0,03$ & $0,52 \pm 0,02$ & 1,4 & 1,7 \\
\hline \multicolumn{7}{|c|}{$\frac{\text { Brachytecium }}{\text { salebrosum }}$} \\
\hline основа & $0,51 \pm 0,03$ & $0,50 \pm 0,04$ & $1,1 \pm 0,09$ & $0,21 \pm 0,01$ & 5,3 & 1,0 \\
\hline схил & - & - & - & - & - & - \\
\hline вершина & $0,38 \pm 0,02$ & $0,32 \pm 0,02$ & $0,70 \pm 0,03$ & $0,20 \pm 0,01$ & 3,5 & 1,1 \\
\hline
\end{tabular}

рослин на схилі. Максимум хлорофілів виявлено у зразках з північного схилу, що зумовлене кращими умовами водозабезпечення рослин на цій частині відвалу. Розміщення мохів на схилі теж суттєво впливало на вміст фотосинтетичних пігментів. Спостерігалася тенденція до зменшення кількості хлорофілів та каротиноїдів у $B$. argenteum та $B$. caespiticium від основи до вершини відвалу, причому це властиве для зразків мохів як з північного, так і південного схилу. Так для зразків виду B. caespiticium, зібраних на вершині відвалу, встановлено зниження вмісту хлорофілів майже на 30\%, порівняно 3 рослинами, що росли в основі відвалу. Тобто, напруженість екологічних факторів, зокрема висока інсоляція (90-110 тис. лк) та зниження вологості субстрату до 4,2-8,5\%, що $є$ характерним для вершини відвалу, суттєво впливали на вміст фотосинтетичних пігментів.

У виду Barbula unguiculata встановлено дещо нижчий рівень зелених пігментів, порівняно $з$ двома попередніми видами (0,6-1,1 мг/г маси с. р.). Цей вид частіше трапляється на відкритих місцезростаннях 3 високою інтенсивністю освітлення, що значно змінює якісний склад його пігментів, оскільки встановлено зменшення відносної частки зелених пігментів i 
зростання вмісту каротиноїдів (0,5-1,2 мг/Г маси с. р.). Співвідношення кількості хлорофілів до каротиноїдів (X/K) у B. unguiculata становить 0,8-1,6. Для B. argenteum та B. caespiticium цей показник вищий і знаходиться у межах 2,0-4,0. У Brachytecium salebrosum співвідношення X/К є найвищим серед усіх досліджуваних видів мохів і досягає 5,3, що $є$ характерним для рослин затінених місцезростань.

Найменшу кількість фотосинтетичних пігментів виявлено у B. salebrosum (0,6-1,1 мг/г маси с. р. хлорофілів та 0,2-0,3 мг/г маси с. р. каротиноїдів). Для цього виду теж спостерігали зниження кількості пігментів майже на $30 \%$ у зразків із вершини, порівняно зі зразками, що росли в основі відвалу. Поряд із кількісними відмінностями, у цього виду встановлені і суттєві якісні зміни у складі зелених пігментів. На території відвалу B. salebrosum росте в затінених місцях, тому пристосованість до низької інтенсивності освітлення у рослин відбувається унаслідок зростання частки хлорофілу $b$ в загальній сумі хлорофілів асимілюючих органів. Загалом, співвідношення хлорофілів $a / b$ у пігментному комплексі листків усіх досліджуваних видів досить низьке (1,01,8), що є близьким до показників рослин тіньового типу [6]. Частка хлорофілу $a$ в сумарній кількості зелених пігментів становить, в середньому, 58-65\% i лише у зразків B. salebrosum цей показник зменшується до 50\% за рахунок підвищення кількості хлорофілу $b$. Це свідчить про широку норму реакції мохів до зміни інтенсивності світла, що дає їм можливість ефективно використовувати низькі інтенсивності освітлення.

Важливим процесом, який визначає життєдіяльність усіх зелених рослин, є асиміляція вуглекислоти. Відомо, що у квіткових рослин у сезонному аспекті проявляється чітка динаміка 3 максимумом інтенсивності газообміну, який приурочений до репродуктивної фази розвитку. У добовій динаміці максимум припадає на передобідню та післяобідню пори і співпадає 3 максимальною освітленістю та температурою $[4,28-30,33]$. У зв’язку 3 унікальною специфікою організації гаметофіту мохів (невеликі розміри, слабкий розвиток ризосфери, примітивна провідна система та інші морфо-фізіологічні 
особливості), можна припустити, що ця група рослин має інші, відмінні від квіткових рослин особливості функціонування фотосинтетичного апарату.

Результати аналізу інтенсивності фотосинтезу домінантних видів мохів на території відвалу №1 підтвердили залежність цього показника як від видових особливостей рослин, так і від конкретних екологічних умов. Максимальну інтенсивність визначено у зразків B. caespiticium та B. argenteum (3,56-3,68 мг $\mathrm{CO}_{2} /$ г маси с. р./год), які росли в основі відвалу (табл. 2).

У B. unguiculata 3 цієї ділянки відвалу показник фотосинтетичної активності становив 3,04-3,41мг $\mathrm{CO}_{2} /$ г маси с. р./год і для B. salebrosum - 2,66 мг $\mathrm{CO}_{2} / г$ маси с. р./год. Найнижчі показники асиміляції $\mathrm{CO}_{2}$ визначені у зразках, відібраних 3 вершини відвалу (2,01-2,61 мг $\mathrm{CO}_{2} / \Gamma$ маси с. р./год), тобто, спостерігається тенденція зниження рівня фотосинтезу від основи до вершини відвалу (аналогічно, як і для фотосинтетичних пігментів). Чітких відмінностей між величинами фотосинтетичної активності залежно від експозиції на північному чи південному схилі не вдалося виявити. У цілому, для усіх досліджуваних видів встановлена пряма кореляція між інтенсивністю фотосинтезу та вмістом хлорофілів у листках мохів, оскільки максимальні величини асиміляціїі $\mathrm{CO}_{2}$ визначені для видів, що мали найбільший вміст зелених пігментів - B. caespiticium та B. argenteum.

Таблиця 2. Інтенсивність фотосинтезу мохів на території відвалу №1.

\begin{tabular}{|c|c|c|}
\hline \multirow{2}{*}{$\begin{array}{c}\text { Місце відбору зразків } \\
\text { мохів }\end{array}$} & $\begin{array}{c}\text { Інтенсивність фотосинтезу, мг } \\
\text { СО2/ г маси сухої речовини/год }\end{array}$ \\
\cline { 2 - 3 } & $\begin{array}{c}\text { Північний } \\
\text { схил }\end{array}$ & Південний схил \\
\hline вryum саеspiticium & $3,64 \pm 0,25$ & \\
\hline гребінь відвалу & $3,57 \pm 0,21$ & $3,64 \pm 0,29$ \\
\hline основа & $2,54 \pm 0,13$ & $2,44 \pm 0,21$ \\
\hline схил & $2,06 \pm 0,09$ & $1,58 \pm 0,09$ \\
\hline вершина & \\
\hline \multicolumn{2}{|c|}{} \\
\hline вгуит агgепtеит & $3,50 \pm 0,14$ & \\
\hline гребіль відвалу & $3,56 \pm 0,18$ & $3,68 \pm 0,21$ \\
\hline основа & $2,56 \pm 0,12$ & $3,23 \pm 0,19$ \\
\hline схил & $2,29 \pm 0,11$ & $2,61 \pm 0,13$ \\
\hline вершина
\end{tabular}




\begin{tabular}{|c|c|c|}
\hline \multicolumn{2}{|c|}{ Barbula unguiculata } & \\
\hline гребінь відвалу & $3,14 \pm 0,25$ & \\
\hline основа & $3,04 \pm 0,22$ & $3,41 \pm 0,21$ \\
\hline схил & $2,31 \pm 0,21$ & $2,53 \pm 0,12$ \\
\hline вершина & $2,22 \pm 0,19$ & $2,32 \pm 0,22$ \\
\hline \multicolumn{2}{|c|}{} \\
\hline Brachytecium salebrosum & - & $2,66 \pm 0,18$ \\
\hline основа & $2,53 \pm 0,13$ & - \\
\hline схил & $2,08 \pm 0,19$ & $2,01 \pm 0,12$ \\
\hline вершина
\end{tabular}

Можливо, одним із лімітуючих факторів вуглекислотного газообміну є оводненість листків мохоподібних, оскільки встановлено зв'язок між величинами інтенсивності фотосинтезу та вмістом вологи у мохових дернинах (рис. 2). Так, на прикладі моху B. argenteum встановлено, що найнижчі покази фотосинтетичної активності (2,29 мг $\mathrm{CO}_{2} / \Gamma$ маси с. р./Год) визначені для рослинних зразків із вмістом вологи $50 \%$. За нижчих значень оводненості рослин відбувається різке падіння інтенсивності фотосинтезу майже до нульових значень.

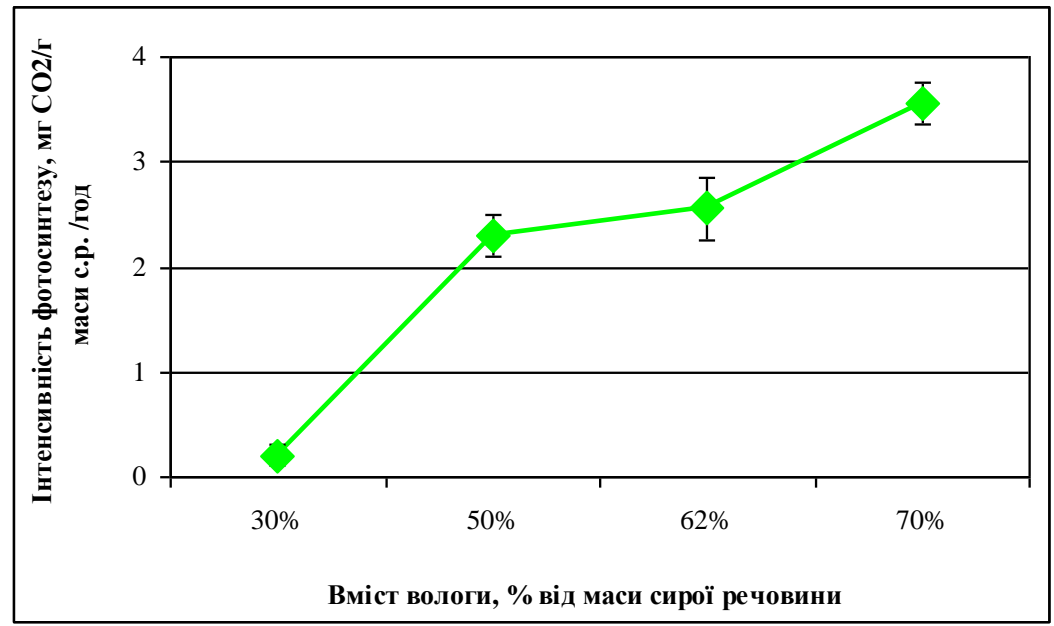

Рис. 2. Вплив ступеня оводненості дернини моху Bryum argenteum на інтенсивність фотосинтезу.

Проаналізовано добову динаміку інтенсивності фотосинтезу у мохів $B$. unguiculata та B. caespiticium і виявлено, що вона має вигляд двовершинної кривої (рис. 3). 


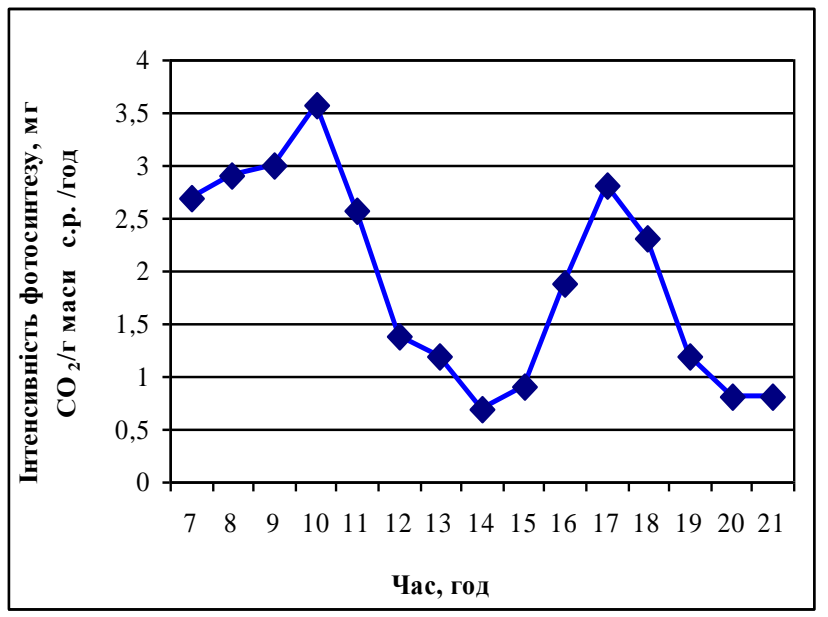

$\mathbf{A}$

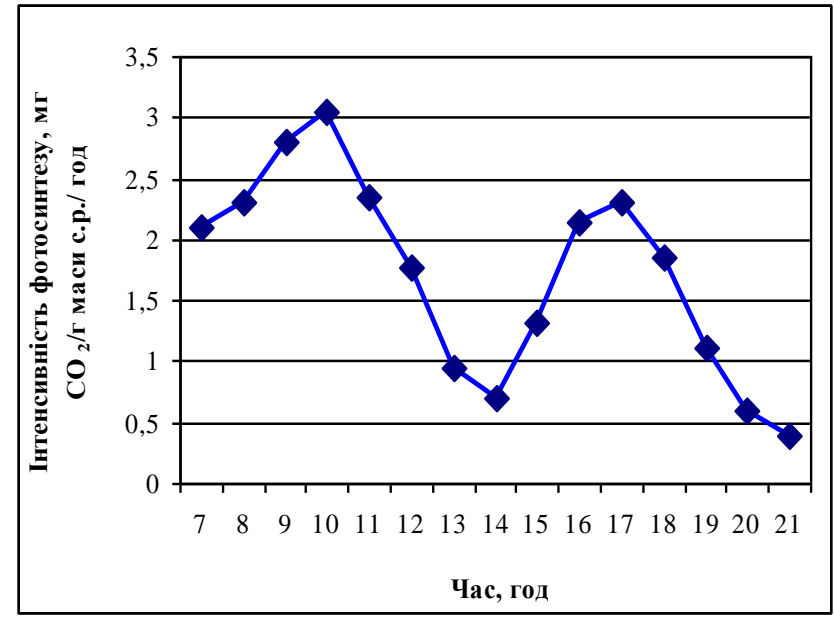

Б

Рис. 3. Добова динаміка інтенсивності фотосинтезу мохів Bryum caespiticium (А) та Barbula unguiculata (Б).

Максимум фотосинтезу (3,67-3,04 мг $\mathrm{CO}_{2} / \Gamma$ маси c.p. /год) припадає на ранкові години (8-10 год), що є характерним для пойкілогідричних видів мохів, для яких лімітаційним чинником фотосинтетичних процесів $є$ вологість. Другий пік активності фотосинтезу (2,3-2,8 мг $\mathrm{CO}_{2} /$ г маси c.p. /год) припадає на післяобідню пору (17-18 год). В умовах максимальної інтенсивності освітлення (12-14 год) виявлено зниження інтенсивності фотосинтезу унаслідок порушення водного й температурного режиму в умовах високого рівня інсоляції.

Отримані результати свідчать про пристосованість фотосинтетичного апарату мохів до контрастних кліматичних умов на території відвалу та здатність підтримувати інтенсивність процесів фотосинтезу на досить стабільному рівні упродовж вегетаційного періоду.

Первинна продуктивність мохового покриву. Основою продукційного процесу рослин $є$ перетворення енергії й утворення органічних речовин у процесі фотосинтезу. У зв'язку з тим, було оцінено внесок бріофітів у первинну продуктивність рослинного покриву на території відвалу сірчаного виробництва. Як показник продуктивності використали хлорофільний індекс (XI), що слугує універсальним параметром для порівняння рослинних 
компонентів різної морфології та систематичного положення. Для його визначення було використано величини вмісту хлорофілів $a$ i $b$ i дані по фітомасі усіх компонентів угруповання. Хлорофільний індекс визначали для мохового угруповання на гребені відвалу 3 домінуванням моху Bryum caespiticium, частка якого становила $52 \%$ від усієї фітомаси. Проективне покриття мохів на досліджуваній ділянці сягало майже 100\%. Видовий склад рослин представлений 3 видами листкостеблових мохів (Bryum caespiticium, B. argenteum, Barbula unguiculata). Виявлено, що запас наземної фітомаси $\epsilon$ суттєво більшим у щільнодернинних видів мохів (B. caespiticium та $B$. argenteum) за рахунок зростання кількості особин на одиницю площі. Встановлено, що величина хлорофільного індексу мохового покриву на гребені відвалу є досить високою і становить 0,563 г/ $\mathrm{M}^{2}$, що зумовлене значною масою асимілюючих органів мохів та високим вмістом в них зелених пігментів (табл. $3)$.

Таблиця 3. Хлорофільний індекс мохового покриву на гребені відвалу.

\begin{tabular}{|c|c|c|c|}
\hline Вид рослин & $\begin{array}{c}\text { Вміст } \\
\text { хлорофілів } \\
(a+b), \text { мг/Г }\end{array}$ & $\begin{array}{l}\text { Запас наземної } \\
\text { фітомаси, г/м² }\end{array}$ & $\begin{array}{l}\text { Хлорофільний } \\
\text { індекс, г/м² }\end{array}$ \\
\hline Bryum caespiticium Hedw. & $\begin{array}{r}\text { маси с. p. } \\
1,231 \pm 0,092\end{array}$ & $253,8 \pm 21,1$ & $0,3681 \pm 0,0211$ \\
\hline Bryum argenteum $\mathrm{L}$. & $1,053 \pm 0,097$ & $56,3 \pm 3,1$ & $0,0593 \pm 0,0034$ \\
\hline Barbula unguiculata Hedw. & $0,743 \pm 0,056$ & $182,5 \pm 16,4$ & $0,1356 \pm 0,0092$ \\
\hline Мохи - всього & & 492,5 & $0,5630 \pm 0,0048$ \\
\hline
\end{tabular}

Цей показник є цілком зіставним з величинами XI, визначеними для рослинних угруповань 3 домінуванням судинних рослин (наприклад, для

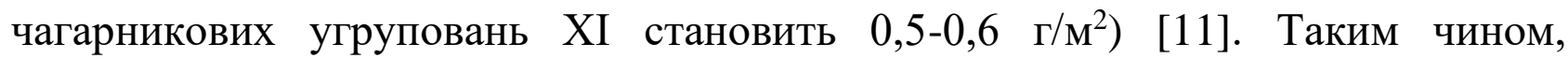
отримані результати засвідчують важливу роль бріофітів у продукційному процесі на техногеннних територіях сірчаного виробництва.

Висновки. На основі результатів аналізу кількісного та якісного складу пігментів пластид у листках домінантних видів мохів відвалу №1 встановлено, 
що бріофіти відзначаються високим вмістом хлорофілів. Рівень вмісту фотосинтетичних пігментів залежить від видових особливостей, приуроченості до умов місцевиростання та від морфологічних характеристик мохів. Насамперед, важливе значення має життєва форма виду, оскільки найвищі показники вмісту фотосинтетичних пігментів встановлені для тих видів, що формують коротку, щільну або пухку дернину (B. caespiticium та B. argenteum). Види 3 такою життєвою формою характеризуються вищою толерантністю до несприятливих екологічних умов на схилах відвалу. Для усіх досліджуваних видів мохів встановлено зниження кількості пігментів фотосинтезу у напрямку від основи до вершини відвалу, незалежно від північної чи південної експозиції. Очевидно, висока інсоляція та нестабільний режим зволоження на вершині відвалу були основними причинами змін у фотосинтетичному апараті мохів. Порівняння середніх показників вмісту хлорофілів у пагонах досліджуваних видів мохів 3 аналогічними показниками, визначеними для інших видів свідчить про подібність пігментного складу мохоподібних із судинними вічнозеленими рослинами [2].

Аналіз інтенсивності фотосинтезу мохів на території відвалу №1 показав залежність цього показника як від видових особливостей рослин, так і від конкретних екологічних умов. Виявлено зниження рівня фотосинтезу мохів від основи до вершини відвалу (аналогічно, як і для фотосинтетичних пігментів). Чітких відмінностей між величинами фотосинтетичної активності залежно від експозиції на північному чи південному схилі не вдалося виявити. Для усіх досліджуваних видів встановлена пряма кореляція між інтенсивністю фотосинтезу та вмістом хлорофілів у листках мохів, оскільки максимальні величини асиміляції $\mathrm{CO}_{2}$ визначені для видів, що мали найбільший вміст зелених пігментів - B. caespiticium та B. argenteum. Добовий перебіг процесу фотосинтезу у мохів на території відвалу сірчаного видобутку має вигляд двовершинної кривої. Максимум фотосинтезу (3,67-3,04 мг $\mathrm{CO}_{2} /$ г маси с.р. /год ) припадає на ранкові години (8-10 год) та післяобідню пору (17-18 год). В умовах максимальної інтенсивності освітлення (12-14 год) виявлено зниження 
інтенсивності фотосинтезу унаслідок порушення водного й температурного режиму в умовах високого рівня інсоляції.

Бріофіти адаптовані до широкого діапазону інтенсивності світла та температурного режиму; здатні до репарації фотосинтетичної діяльності після сухих періодів влітку. Такі особливості фотосинтетичної активності бріофітів значно підвищують первинну продуктивність тих рослинних угруповань, де вони $є$ піонерами заростання. Встановлено, що величина продуктивності (хлорофільний індекс) мохового покриву на гребені відвалу є досить високою і становить 0,563 г/м², що зумовлене значною масою асимілюючих органів мохів та високим вмістом в них зелених пігментів. Цей показник $є$ цілком зіставним 3 величинами XI, визначеними для рослинних угруповань 3 домінуванням судинних рослин.

Таким чином, еколого-фізіологічна оцінка домінуючих видів мохів на території відвалу сірчаного видобутку гірничо-хімічного підприємства «Сірка» свідчить про важливу роль цих рослин у процесах відновлення техногенних ландшафтів сірчаних родовищ $\mathrm{i}$ необхідність продовження вивчення особливостей функціонування рослинних угруповань 3 домінуванням мохоподібних.

Створення регіональної програми комплексних мультидісциплінарних досліджень буде сприятиме вивченню причин та умов, що спричиняють забруднення вод, що призводить до виникнення різноманітних захворювань населення, зниження загальної резистентності організму i, як наслідок, до підвищення рівня загальної захворюваності, зокрема на інфекційні та онкологічні захворювання.

Проведені дослідження $є$ підтвердженням актуальності питань охорони природи, ревіталізації техногенно порушених територій, відновлення біорізноманіття, під час вивчення студентами таких дисциплін, як «Фармацевтична ботаніка», «Медична екологія», «Ресурсознавство лікарських рослин», «Фармакогнозія», «Клінічна фармація». 


\section{Література.}

1. Bazilevich N.I., Titlyanova A.A., Smirnov V.V. and other Methods of studying the biological circulation in various natural zones. University Press, Moscow, "Science", 1978. - 349 p.

2. V.L. Voznesensky On carbon dioxide gas exchange of plants / V.L. Voznesensky // Plant Physiology. - 1986. - 33 (2). - P. 305-312.

3. Didukh O.I., Malovany M.S., Shpakivska I.M. Physical properties of soils within the post-technogenic landscape of Yavoriv DGHP "Sulfur". Bulletin of the National University "Lviv Polytechnic". - 2008. - 609. - P. 225-233.

4. Zalensky O.V. Photosynthesis of plants in natural conditions // Questions of botany. M.; L.: Publishing house of the Academy of Sciences of the USSR, 1978. Issue. 1. - P. 59-87.

5. Kozlovsky V. Heavy metals in soils of technogenic landscapes of native sulfur deposits of Precarpathia (Ukraine) / V. Kozlovsky // Soil Science. - 2008. - 9, № 3. - P. 101-107.

6. Lukyanova L.M., Lokteva T.N., Bulycheva T.M., Kudryavtseva O.V. Gazoobmen i pigmentnaya sistema Kol'skoy Subarktiki. Gas exchange and pigment system of the Kola Subarctic. Apatity, 1986. - 127 p.

7. O. Maryskevych, V. Levyk, I. Shpakivska, M. Brzhezhinska // Naukovyj visnyk Uzhhorodskoho un-tu. The series is biological. - 2008. - 24. - P. 78-82.

8. Mariskevich O.G Formation of soils within the technogenic landscape of Yavoriv DGHP "Sirka" / O.G. Mariskevich, I.M Shpakivska, O.I Didukh // Scientific Bulletin of Chernivtsi University. The series is biological. - 2005. - 251. - P. 175185.

9. Mineev V.G. Praktikum po agrokhimii. Workshop on agrochemistry. Moscow University Press, Moscow, 1989. - 304 p.

10. Nikolaychuk V.I. Special workshop on plant physiology and biochemistry. Uzhhorod, 2000. -210 p. 
11. The production process in the communities of the mountain tundra Khibiny / Shmakova N.Yu., Lukyanova L.M., Bulycheva T.M., Kudryavtseva O.V. Apatity, 1996. - 125 p.

12. Plokhinsky N.A. Biometrics / N.A. Plokhinsky. Moscow University Press, Moscow, 1970. - 367 p.

13. Rabyk I., Danylkiv I., Shcherbachenko O. Structure and dynamics of bryophyte groups in the devastated lands of Lviv region (on the example of the dump of the mining and chemical enterprise "Sirka") / Visnyk of Lviv. University. - 2010. - 53. - P. 58-66.

14. Shmakova N.Yu., Lukyanova L.M., Bulycheva T.M., Kudryavtseva O.V. Production process in the Khibiny mountain tundra communities. Apatity, 2006. $125 \mathrm{p}$.

15. Arnon D. Copper enzymes in isolated chloroplasts. Polyphenol oxidase in Beta vulgaris / D. Arnon // Plant Physiol. - 1949. - 24. - P. 1-15.

16. Bryophyte Biology. A. Jonathan Shaw and Bernard Goffinet [eds.]. Cambridge University Press. - 2000. - 476 p.

17. During H.J. The bryophytes of calcareous grasslands. In: Hillier S.H., Walton D.W.H., and Wells D.A. (eds.), Calcareous Grasslands. Ecology and Management. Proceedings of a Joint British Ecological Society / Nature Conservancy Council Symposium (14-16 September, 1990), University of Sheffield. - P. 35-40.

18. During H.J., Lloret F. Permanent grid studies in bryophyte communities 1. Pattern and dynamics of individual species / J. Hattori Bot. Lab. - 1996 - Vol. 79. P. 1-41.

19. Glime J.M. Bryophyte Ecology. Volume 1. Physiological Ecology. - 2007. - E-book sponsored by Michigan Technological University and the International Association of Bryologists. Accessed on March 2008. URL: http://www.bryoecol.mtu.edu/.

20. Glime J.M. Photosynthesis in aquatic bryophytes. In: Hanson D.T., Rice S.K., eds. Photosynthesis in Bryophytes and Early Land Plants. Dordrecht: Springer, 2014. - P. 201-232. 
21. Longton R.E. The role of bryophytes in terrestrial ecosystems / J. Hatt. Bot. Lab. - 1984. - Vol. 55. - P. 147-163.

22. Longton R.E. Biology of Polar Bryophytes and Lichens. Cambridge: Cambridge University Press, 1988. - 324 p.

23. Longton R.E. The role of bryophytes and lichens in terrestrial ecosystems. In: Bryophytes and Lichens in a Changing Environment / Eds. J.W. Bates and A. M. Farmer. Clarendon Press, Oxford, 1992. - P. 32-76.

24. Monforte, L., Soriano, G., Núñez-Olivera, E., and Martínez-Abaigar, J. Cell compartmentation of ultraviolet-absorbing compounds: an underexplored tool related to bryophyte ecology, phylogeny and evolution / Funct. Ecol. - 2018. - Vol. 32. - P. 882-893. DOI: 10.1111/1365-2435.13048

25. Poorter, H., Niinemets, U., Ntagkas, N., Siebenkäs, A., Mäenpää, M., Matsubara, S. A meta-analysis of plant responses to light intensity for 70 traits ranging from molecules to whole plant performance / New Phytol. - 2019. - Vol. 223. - P. 1073-1105. DOI: 10.1111/nph.15754

26. Porada P., Weber B., Elbert W., Pöschl U., Kleidon A. Estimating impacts of lichens and bryophytes on global biogeochemical cycles / Global Biogeochemical Cycles. - 2014. - Vol. 28. - P. 71-85. doi:10.1002/2013GB004705.

27. Proctor M.C.F. Ecophysiological measurements on two pendulous forest mosses from Uganda, Pilotrichella ampullacea and Floribundaria floribunda / J. Bryol. - 2002. - Vol. 24. - P. 223-232.

28. Proctor, M. C. F., and Smirnoff, N. Photoprotection in bryophytes: rate and extent of dark relaxation of non-photochemical quenching of chlorophyll fluorescence / J. Bryol. - 2015. - Vol. 37. - P. 171-177. DOI:10.1179/1743282015Y.0000000001.

29. Proctor M.C.F., Bates J.W. Chlorophyll-fluorescence measurements in bryophytes: Evidence for three main types of light-curve response / J. Bryol. - 2018. - Vol. 40. - P. 1-11. https://doi.org/10.1080/03736687.2017.1407280. 
30. Raven J.A., Colmer T.D. Life at the boundary: photosynthesis at the soilfluid interface. A synthesis focusing on mosses / Journal of Experimental Botany. 2016. - Vol. 67, № 6. - P. 1613-1623. https://doi.org/10.1093/jxb/erw012.

31. Rieley J.O., Richards P.W., Bebbington A.D.L. The ecological role of bryophytes in a north-Wales woodland / J. Ecol. - 1979. Vol. 67. P. 497-527.

32. Ringen D. The role of moss in facilitating natural revegetation of metalcontaminating sites during primary succession / D. Ringen // URL: www.bioed.org/ibscore/.

33. Ruchika, C.Z., Péli E.R. Seasonality and Small Spatial-Scale Variation of Chlorophyll $a$ Fluorescence in Bryophyte Syntrichia ruralis Hedw. in Semi-Arid Sandy Grassland, Hungary / Plants. - 2020. - Vol. 9, № 1. - P. :92. https://doi.org/10.3390/plants9010092.

34. Schofield W.B. Introduction to Bryology. - 1985, New York, Macmillan Publishing Company. -248 p.

35. Soriano G., Del-Castillo-Alonso M.-Á., Monforte L., Núñez-Olivera E., Martínez-Abaigar J. Acclimation of bryophytes to sun conditions, in comparison to shade conditions, is influenced by both photosynthetic and ultraviolet radiations / Frontiers in Plant Science. - 2019. - Vol. 10. - P. 998-1014. https://doi.org/10.3389/fpls.2019.00998.

36. Thornton L. E., Keren N.,Ohad I., Pakrasi H. B. Physcomitrella patens and Ceratodon purpureus, mosses as model organisms in photosynthesis studies. I Photosynth Res. - 2005. - Vol. 83, - № 1. - P. - 87-96. //doi: 10.1007/s11120-0045577-3.

37. Kyyak N. Photosynthetic activity of the mosses on the devastated territories of sulphur extraction // Visnyk of the Lviv University. Series BIology. 2013. Issue 62. P. 170-179. URL: http://prima.Inu.edu.ua/faculty/biologh/wis/62/5/22/22.pdf.

38. Zakon Ukrainy «Pro Osnovni zasady (stratehiiu) derzhavnoi ekolohichnoi polityky Ukrainy na period do 2030 roku»//Vidomosti Verkhovnoi Rady (VVR), 2019, № 16, st.70. 
39. Trakhtenberg I.M., Dmytrukha N.M., Korolenko T.K., Lahutina O.S. Bakalo L.V., Lehkostup L.A. Experimental study of the influence of $\mathrm{Fe}_{2} \mathrm{O}_{3}$ nanoparticles on the rats isolated and in the background of application of the preparation «Quercetin» // Ukrainian Journal of Occupational Health. - 2021 . - №17 (1). - P. 3-14.

40. Dzhumelia E.A. Ekolohichna bezpeka hirnycho-khimichnoho pidpryiemstva na stadii likvidatsii. Dysertatsiia na zdobuttia naukovoho stupenia doktora filosofii. Natsionalnyi universytet «Lvivska politekhnika», Lviv. 2020. S. 154-155.

41. Pohrebennyk V.D., Dzhumelia E.A. Ekolohichnyi monitorynh pidzemnykh vod hirnycho-khimichnoho pidpryiemstva na stadii likvidatsii // VII-y Vseukrainskyi zizd ekolohiv z mizhnarodnoiu uchastiu (Ekolohiia/Ecology-2019), 25-27 veresnia, 2019. Zbirnyk naukovykh prats. Vinnytsia: VNTU, 2019. S. 109. 